\title{
Pelatihan Peningkatan Produktivitas dan Bimbingan Konsultasi dalam Rangka Peningkatan Produktivitas Tenaga Kerja Indonesia
}

\author{
Yeni Nuraeni ${ }^{1}$ \\ ${ }^{1}$ Pusat Pengembangan Kebijakan Kementerian Ketenagakerjaan, Jakarta \\ yeninur@hotmail.com
}

\begin{abstract}
Abstrak
Persentase produktivitas tenaga kerja Indonesia masih tergolong rendah yaitu baru mencapai $74.4 \%$, masih berada di bawah rata-rata negara-negara ASEAN yang sudah mencapai $78,2 \%$. Pemerintah melakukan berbagai upaya untuk mendorong peningkatan produktivitas tenaga kerja salah satunya dengan memberikan Pelatihan Peningkatan Produktivitas dan Bimbingan Konsultasi kepada perusahaan dan tenaga kerjanya. Adapun tujuan dari program Pelatihan Peningkatan Produktivitas adalah untuk memberikan pengetahuan dan keterampilan kepada tenaga kerja berkaitan dengan alat dan teknik peningkatan produktivitas untuk dapat diimplementasikan di tempat kerjanya. Sedangkan program Bimbingan Konsultasi bertujuan untuk membimbing perusahaan agar meningkat produktivitasnya dengan mengidentifikasi permasalahan yang dihadapi perusahaan serta melakukan langkah-langkah pemecahan dan memberikan rekomendasi dalam rangka perbaikan peningkatan produktivitas. Metode yang digunakan dalam program peningkatan produktivtas adalah dengan memberikan pengetahuan dan keterampilan kepada tenaga kerja dan pihak manajement perusahaan serta langsung mengaplikasikannya di tempat kerja/perusahaan. Perusahaan beserta tenaga kerjanya yang telah mendapatkan program pelatihan dan bimbingan untuk peningkatan produktivitas terus dilakukan pembinaan oleh instansi terkait serta difasilitasi untuk dapat menunjukkan peningkatan kinerjanya dan mendapatkan penghargaan di tingkat Provinsi maupun di tingkat Nasional. Perbaikan yang diperlukan pada program pelatihan peningkatan produktivitas adalah dengan praktek langsung di tempat kerja dan tidak banyak dilakukan di dalam kelas. Program yang diluncurkan pemerintah merupakan stimulus bagi perusahaan-perusahaan di Indonesia untuk lebih meningkatkan kesadaran berkaitan dengan pentingnya peningkatan produktivitas.
\end{abstract}

Kata kunci : Produktivitas Tenaga Kerja, Pelatihan Peningkatan Produktivitas, Bimbingan Konsultasi Peningkatan Produktivitas

\section{Pendahuluan}

Berdasarkan penelitian Institute for Management Development (IMD), daya saing tenaga kerja Indoneisa masih tertinggal dibandingkan sejumlah negara ASEAN seperti Thailand, Malaysia, dan Singapura. Sementara secara global, Indonesia berada di peringkat 47 dari 63 negara seperti terlihat pada gambar 1. 


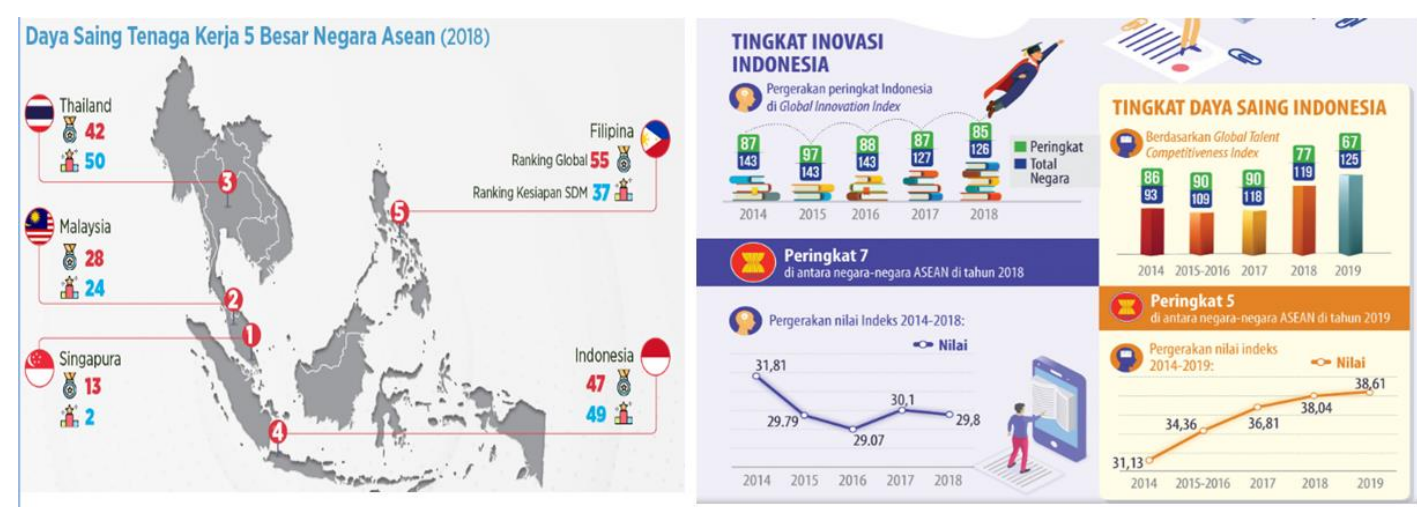

Gambar 1. Perbandingan Tingkat Daya Saing Tenaga Kerja Negara Indonesia dibandingkan dengan Negara-Negara di ASEAN (Sumber: Gugustomo, 2019)

Sejumlah persoalan masih dihadapi Indonesia seperti rendahnya pendidikan pekerja serta ketidaksesuaian (mismatch) antara pendidikan dengan pekerjaan yang merupakan salah satu faktor penyebab rendahnya daya saing Indonesia. Menurut data Badan Pusat Statistik (BPS) per Februari 2019, pendidikan pekerja Indonesia didominasi oleh lulusan SD ke bawah sebanyak 52,40 juta pekerja. Sedangkan menurut Survei Angkatan Kerja Nasional 2015, ketidaksesuaian antara pekerjaan dengan latar pendidikan masih cukup tinggi yakni sebesar $60,52 \%$. Adapun penyumbang ketidaksesuaian pekerjaan dengan pendidikan terbesar berasal dari sektor pertanian. Demi mengatasi daya saing tenaga kerja Indonesia yang masih tertinggal, pemerintah mengupayakan berbagai program seperti pelatihan vokasi, pemagangan berbasis kompetensi di perusahaan, dan sertifikasi kompetensi. Program tersebut dicanangkan dalam rangka pemenuhan tenaga kerja sesuai kebutuhan industri serta meningkatkan serapan tenaga kerja. Persoalan tenaga kerja di Indonesia bisa dilihat pada gambar 2.

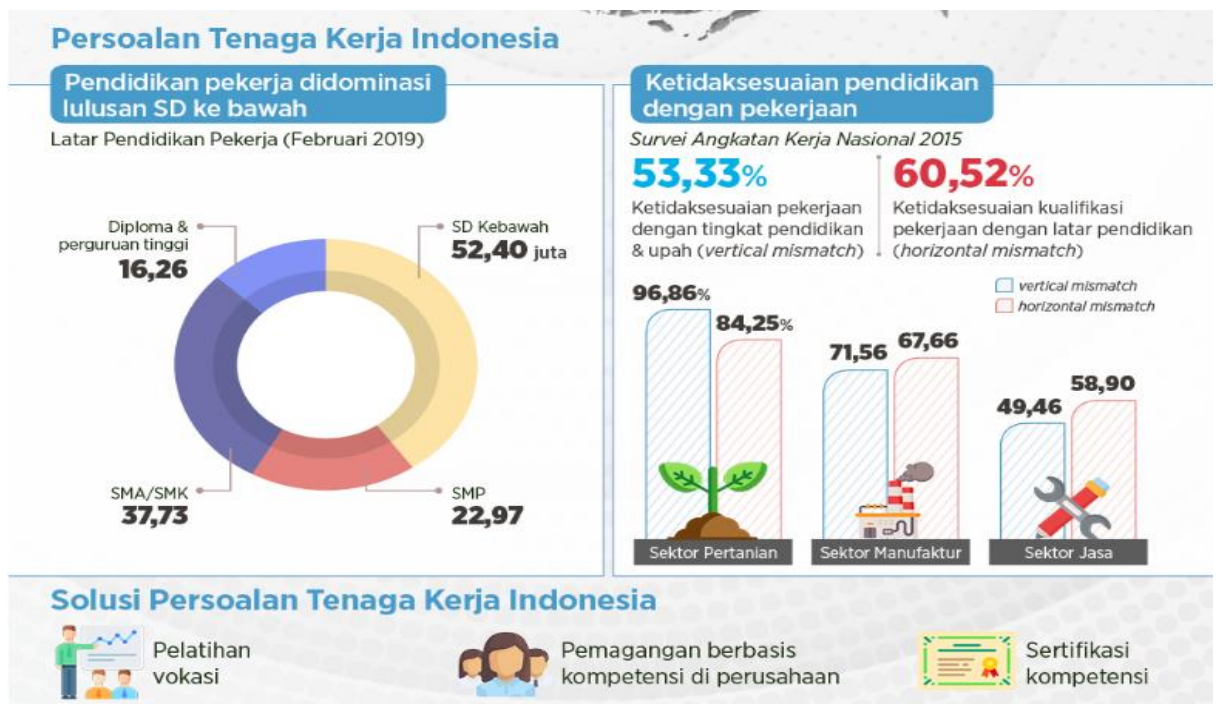

Gambar 2. Perbandingan Tingkat Daya Saing Negara Indonesia di Bandingkan Dengan Negara-Negara di ASEAN (Sumber :Anon, 2019)

JCommdev Vol 2, No. 3, 2021, hlm. 94 - 105 
Kondisi tingkat Produktivitas tenaga kerja Indonesia masih rendah dibandingkan dengan negara-negara di Asia maupun di ASEAN demikian pula walaupun memiliki kecenderungan terus meningkat tetapi tingkat pertumbuhan Produktivitas Indonesia masih rendah dibandingkan dengan negara-negara lainnya misalnya Vietnam, Thailand, Myanmar, Malaysia, dan Filipina. Peningkatan produktivitas merupakan kebutuhan yang mendesak untuk meningkatkan daya saing nasional, daerah dan juga lembaga-lembaga wirausaha dan organisasi lainnya. Kunci peningkatan produktivitas, daya saing dan kemajuan daerah atau Negara bertumpu kepada kemampuan peningkatan produktivitas itu sendiri melalui peningkatan produktivitas tenaga kerja (labor productivity), produktivitas modal (capital productivity) dan produktivitas total (total productivity).

Upaya peningkatan produktivitas diharapkan berdampak pada perbaikan daya saing tenaga kerja Indonesia yang saat ini dalam World Economic Forum (WEF) menempati posisi 50 dari 141 negara. Beberapa hal yang menghambat Indonesia dalam meningkatkan daya saing a.I. korupsi, permasalahan birokrasi dan infrastruktur (Dwi 2019). Hubungan industri yang baik dinilai menjadi faktor pendorong bagi produktivitas. Lalu ada perselisihan antara pekerja dan perusahaan terkait permintaan upah dan tenaga kerja. Peningkatan produktivitas tenaga kerja Indonesia dapat dilakukan dengan peningkatan kompetensi pekerja. Saat ini terdapat 302 BLK yang berada di bawah pengelolaan pemerintah pusat, provinsi maupun kabupaten/kota. Peningkatan produktivitas tenaga kerja ini sangat tergantung pada kesungguhan dan komitmen Pemerintah Indonesia bersama dengan pelaku usaha.

Terdapat beberapa strategi serta implementasi dari strategi produktivitas, yaitu:

1. Penyadaran Produktivitas: Pada strategi ini implementasinya yaitu promosi produktivitas untuk memberikan pemahaman dan penyebarluasan konsepsi produktivitas guna meningkatkan kesadaran produktivitas

2. Peningkatan Produktivitas: Pada strategi ini implementasinya yaitu dengan cara melalui pengembangan budaya produktif, peningkatan kualitas SDM, inovasi teknologi, dan pengembangan manajemen, serta implementasinya dengan melakukan pengukuran produktivitas individu, mikro/perusahaan, dan makro/nasional

3. Pemeliharaan Produktivitas: Pada strategi ini implementasinya yaitu dengan cara melalui pembakuan dan pelestarian teknik dan metode peningkatan produktivitas

Kementerian Ketenagakerjaan melalui Direktorat Jenderal Pembinaan Pelatihan dan Produktivitas telah memiliki program-program yang ditujukan untuk mengupayakan peningkatan produktivitas tenaga kerja di Indonesia, diantaranya melalui program "Pelatihan Peningkatan Produktivitas dan Bimbingan Konsultasi Peningkatan Produktivitas".

Untuk memenuhi kebutuhan peningkatan produktivitas nasional ada beberapa hal yang perlu dilakukan salah satunya dengan peningkatan produktivitas tenaga kerja dan penguatan 
daya saing perusahaan termasuk pada instansi pemerintah, terkait dengan peningkatan produktivitas tenaga kerja dapat dilakukan melalui kegiatan Pelatihan Peningkatan Produktivitas, kegiatan ini merupakan salah satu program yang dilakukan oleh Direktorat Jenderal Pembinaan Pelatihan dan Produktivitas Kementerian Ketenagakerjaan. Tujuan dari kegiatan ini adalah peningkatan produktivitas tenaga kerja melalui pembangunan kesadaran pekerja akan pentingnya produktivitas, memberikan pemahaman tentang penerapan teknik-teknik atau metoda peningkatan produktivitas di tempat kerja serta metode untuk memelihara tingkat produktivitas yang telah dicapai. Adapun konsep dari pelatihan peningkatan produktivitas ditunjukan pada gambar 3. Kegiatan ini memfokuskan pada peningkatan produktivitas perusahaan melalui tenaga kerjanya, oleh karena tenaga kerja yang menjadi fokus utama dalam kegiatan.

\section{PELATIIIAN PENINGRATAN PRODUIKTIVITAS}

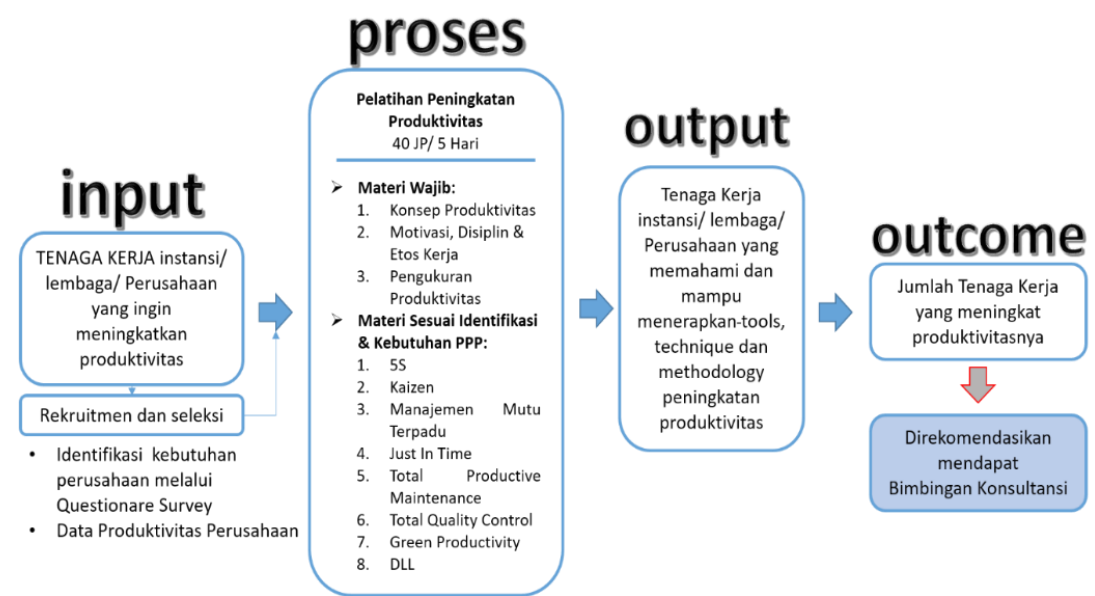

Gambar 3. Konsep Pelatihan Peningkatan Produktivitas

Sumber : (Anon 2020b)

Pelatihan peningkatan produktivitas tenaga kerja bertujuan meningkatkan keterampilan dan pengetahuan para pekerja tentang alat teknik dan metode peningkatan produktivitas untuk di implementasikan ditempat kerjanya. Dalam rangka kesinambungan program Direktorat Jenderal Pembinaan Pelatihan dan Produtivitas juga memiliki program yang dilakukan pasca mengikuti pelatihan peningkatan produktivitas yaitu kegiatan Bimbingan Konsultansi peningkatan produktivitas pada perusahaan yang tenaga kerjanya telah mengikuti pelatihan peningkatan produktivitas dalam rangka mempastikan pengetahuan dan keterampilan yang diperoleh diimplementasikan ditempat kerjanya. Kegiatan bimbingan konsultansi dilakukan dengan tujuan agar tercapai peningkatan produktivitas perusahaan melalui penekanan segala bentuk pemborosan ditempat kerja dengan cara penerapan alat teknik dan metode peningkatan produktivitas. Kegiatan Bimbingan Konsultansi Peningkatan Produktivitas merupakan kegiatan yang dirancang untuk mengembangkan dan meningkatkan produktivitas usaha kecil dan menengah (UKM). Konsep pelaksanaan kegiatan Bimkon yang dapat dijelaskan dalam gambar 4. 


\section{input}

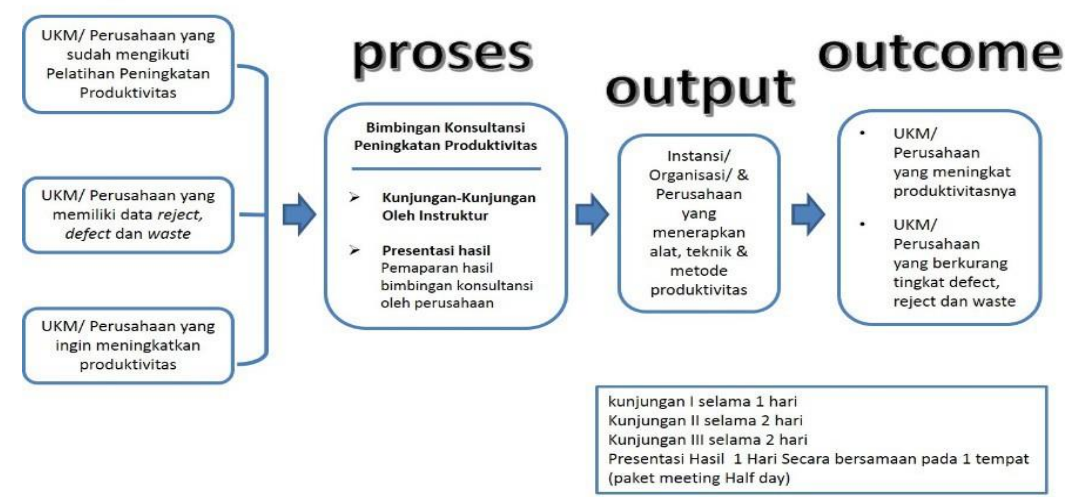

Gambar 4. Konsep Bimbingan Konsultansi Peningkatan Produktivitas

Sumber: (Anon 2020a)

Pelaksanaan Pelatihan Peningkatan Produktivitas dan Bimbingan Konsultasi dilakukan di seluruh wilayah Indonesia bekerja sama dengan Dinas Provinsi, Kabupaten, Kota yang membidangi ketenagakerjaan. Gambar 5 menunjukkan sebaran pelaksanaan Pelatihan Peningkatan Produktivtas dan Bimbingan Konsultasi di seluruh wilayah Indonesia.
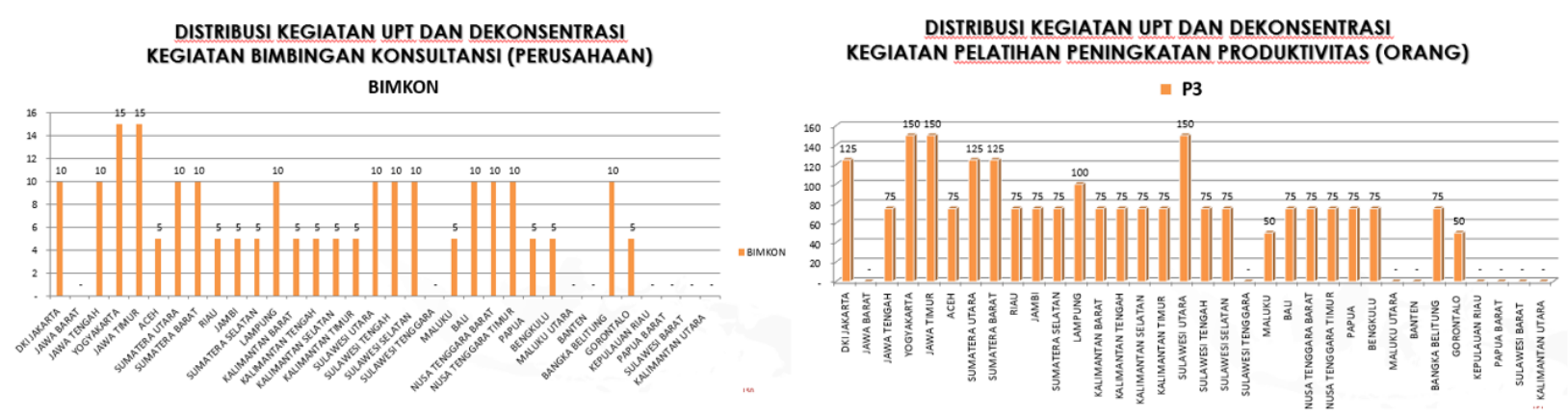

Gambar 5: Distribusi Pelaksanaan Pelatihan Peningkatan Produktivitas dan Bimbingan Konsultasi Tahun 2020

\section{Metode Pelaksanaan}

\section{Pelatihan Peningkatan Produktivitas}

Pelatihan peningkatan produktivitas dilakukan pada perusahaan yang ingin meningkatkan produktivitasnya dengan mengurangi tingkat pemborosan pada setiap penggunaan Input seperti Tenaga Kerja, Modal, Metode Kerja, Bahan Baku dan Mesin atau Peralatan (5M) yang digunakan dalam melakukan kegiatan produksi. Pelatihan peningkatan produktivitas ini ditujukan kepada tenaga kerja suatu perusahaan yang dilaksanakan selama 5 hari (40 Jam Latihan @ 45 menit).

Materi pelatihan terdiri dari materi wajib dan materi pilihan. Materi wajib adalah materi yang wajib diberikan pada setiap penyelenggaraan pelatihan agar para peserta pelatihan memiliki pemahaman awal yang sama mengenai pentingnya peningkatan produktivitas bagi pekerja. 
Materi wajib juga memberikan pemahaman kepada pekerja tentang bagaimana memulai menjadi kader produktivitas di perusahaan tempat mereka bekerja. Materi wajib terdiri dari;

- Konsep Produktivitas....................................................... 2 JP

- Motivasi, Disiplin dan Etos Kerja ....................................... 2 JP

- Pengukuran Produktivitas .......................................... 4 JP

- Penyusunan Action Plan ............................................... 2 JP

Materi pilihan berisikan materi pelatihan yang dipilih berdasarkan hasil identifikasi kebutuhan peningkatan produktivitas diperusahaan peserta pelatihan. Meteri pilihan dapat disesuaikan dengan alokasi waktu yang tersedia setelah materi wajib disampaikan, dibawah ini beberapa materi pilihan:

- $5 \mathrm{~S}$ $30 \mathrm{JP}$

- Kaizen $30 \mathrm{JP}$

- Manajemen Mutu Terpadu $30 \mathrm{JP}$

- Just In Time $30 \mathrm{JP}$

- Total Productive Maintenance $30 \mathrm{JP}$

- Total Quality Control $30 \mathrm{JP}$

- Green Productivity. $30 \mathrm{JP}$

Peserta pelatihan peningkatan produktivitas sebanyak 25 orang pada setiap kelas / setiap paket pelatihan yang berasal dari perusahaan yang ingin meningkatkan produktivitasnya. Proses seleksi calon peserta pelatihan peningkatan produktivitas dilaksanakan melalui seleksi kelengkapan administrasi dan dengan melihat tingkat kesesuaian/ relevansi antara jabatan, keahlian dengan program pelatihan, melalui formulir biodata calon peserta dan kuesioner yang telah diisi oleh calon peserta pelatihan. Dalam pelaksanaan rekrutmen dan seleksi pelaksana pusat dan pelaksana daerah melakukan koordinasi internal, instansi terkait dan dunia usaha untuk sinergitas program yang berkelanjutan. Koordinasi bertujuan agar calon peserta pelatihan peningkatan produktivitas tenaga kerja setelah mengikuti pelatihan sanggup menerapkan hasil pelatihan untuk peningkatan produktivitas.

Penggunaan metode pelatihan disesuaikan dengan jenis alat, teknik dan metode produktivitas yang akan disampaikan. Metode yang digunakan dalam pelaksanaan pelatihan peningkatan produktivitas adalah ; Ceramah/Diskusi, Plant Tour, Praktek Penerapan Alat, Teknik Peningkatan Produktivitas, Presentasi.

Evaluasi capaian peserta dilakukan untuk mengetahui sejauh mana pemahaman peserta pelatihan terhadap materi pelatihan yang diberikan oleh instruktur melalui action plan yang 
disusun. Peserta yang dapat menyelesaikan action plan dengan ketentuan yang telah ditetapkan sebelumnya akan dinyatakan lulus dan dapat diberikan Sertifikat Pelatihan. Sedangkan peserta yang belum dapat menyelesaikan action plan akan diberikan Surat Keterangan Telah Mengikuti Pelatihan.

\section{Bimbingan Konsultasi Peningkatan Produktivitas}

Pelaksanaan bimbingan konsultansi perusahaan dibagi atas dua skema yaitu; pertama perusahaan yang telah mengikuti Pelatihan Peningkatan Produktivitas dan yang kedua yaitu tanpa didahului Pelatihan Peningkatan Produktivitas. Pelaksanaan Bimbingan Konsultasi dilakukan melalui kunjungan oleh konsultan ke perusahaan-perusahaan dengan skema seperti terlihat pada gambar 5 .

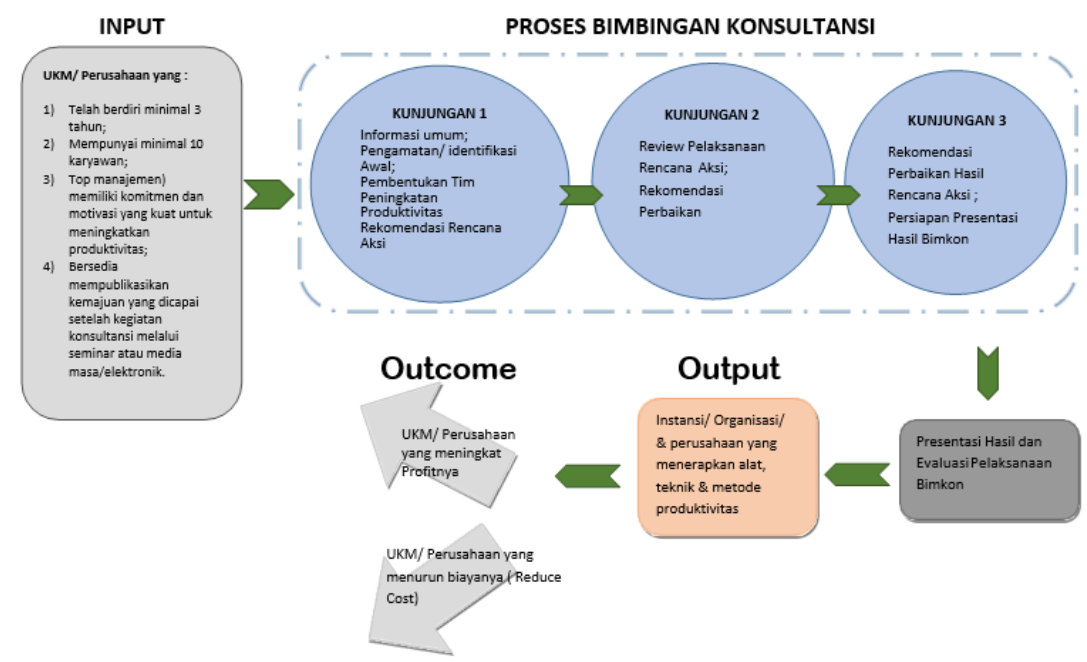

Gambar 5. Skema Bimbingan Konsultansi Peningkatan Produktivitas Sumber : (Anon 2020a)

Pelaksanaan Bimbingan Konsultansi dilaksanakan di perusahaan UKM dilaksanakan selama 3 (tiga) kali tahapan meliputi :

\section{a. Tahapan Pertama (I).}

- Melaksanakan Sosialisasi Program Bimbingan Konsultasi pada perusahaan Bimbingan tentang penyampaian informasi umum, latar belakang kegiatan, tujuan dan proses Bimkon.

- Melakukan Pengamatan/ identifikasi Awal: Melakukan plant tour untuk mengidentifikasi masalah dan penyebabnya, serta alternatif solusinya.

- Pembentukan Tim Peningkatan Produktivitas perusahaan Binaan yang akan menindaklanjuti Rencana Aksi

- Menetapkan Rekomendasi Rencana Aksi 


\section{b. Tahapan Kedua (II).}

- Review Pelaksanaan Rencana Aksi; meninjau perkembangan pelaksanaan rencana aksi, membandingkan antara target dengan progress di lapang.

- Rekomendasi Perbaikan; memberikan saran perbaikan/ penyesuaian jika diperlukan.

c. Tahapan Ketiga (III).

- Rekomendasi Perbaikan Hasil Rencana Aksi; memberikan saran perbaikan/ penyesuaian jika diperlukan

- Persiapan Presentasi Hasil Bimkon; memberikan pendampingan menyusun presentasi hasil Bimbingan Konsultasi.

Dalam pelaksanaan Bimbingan Konsultansi, perusahaan bimbingan didukung dengan pemberian bahan perbaikan kondisi kerja sesuai dengan kebutuhan action Plan di masing-masing perusahaan (UKM). Jika dibutuhkan, perusahaan dapat menyiapkan bahan tambahan dalam rangka optimalisasi pelaksanaan action plan. Dan pada akhir pelaksanaan pendampingan, peserta Bimbingan Konsultasi (Bimkon) menyampaikan presentasi hasil dan evaluasi pelaksanaan hasil Bimkon dan demikian juga dengan instruktur wajib untuk menyampaikan laporan paripurna pelaksanaan pendampingan terhadap UKM secara tertulis kepada unit kerjanya.

\section{Hasil Kegiatan dan Pembahasan}

\section{a. Pelatihan Peningkaktan Produktivitas}

Karyawan dan perusahaan merasakan berbagai manfaat dari Pelatihan Peningkatan Produktivitas antara lain; menambah ilmu pengetahuan berkaitan dengan produktivitas dan dapat mempraktekkannya di tempat kerja dengan cara bekerja lebih berstruktur, dapat merencanakan alur kerja perusahaan menjadi lebih efesien, dapat merubah kebiasaan keseharian karyawan di luar tempat kerja atau di rumah untuk selalu dapat menerapkan budaya kerja produktiv, memberikan motivasi baru yang dapat menjadi pemicu semangat untuk meningkatkan produktivitas serta menjaga situasi psikologi seseorang di tempat kerja sehingga dikondisikan untuk tetap fokus kerja dan produktif.

Pelatihan peningkatan Produktivitas lebih difokuskan pada level dasar/foundation di antaranya 5S dan Kaizen, karena untuk level perusahaan UKM di Indonesia level dasar pada umumnya belum menjadi budaya kerja di perusahaan sehingga perlu diperkuat sebelum meningkat ke level berikutnya. Selain itu untuk dapat menyelenggarakan pelatihan peningkatan produktivitas level basic maupun advanced terkendala dengan keterbatasan kompetensi yang dimiliki oleh instruktur.

Good house Keeping atau $5 \mathrm{~S}$ adalah suatu teknik untuk meminimalisasi pemborosan atau hal-hal yang terbuang percuma di tempat kerja. Pijakan awal dari penerapan 55 adalah karena adanya ketidakrapian, area kerja yang berantakan sehingga menjadi tidak produktif. 5S 
merupakan elemen penting dari "Lean Thinking" dan "Visual Workplace" yang dapat menciptakan tampilan yang fundamental untuk pabrik kelas dunia dan merupakan dasar dari semua program peningkatan kualitas (Anon 2015). Adapun Kaizen berarti "Improvement" yang merupakan upaya perbaikan secara terus menerus tanpa akhir. Kaizen adalah suatu strategi yang mengharuskan setiap orang dalam suatu organisasi mulai dari yang paling atas sampai ke tingkat paling bawah, untuk terus-menerus melakukan perbaikan. Alat Teknik, dan metode peningkatan produktivitas bisa dilihat pada gambar 6 .

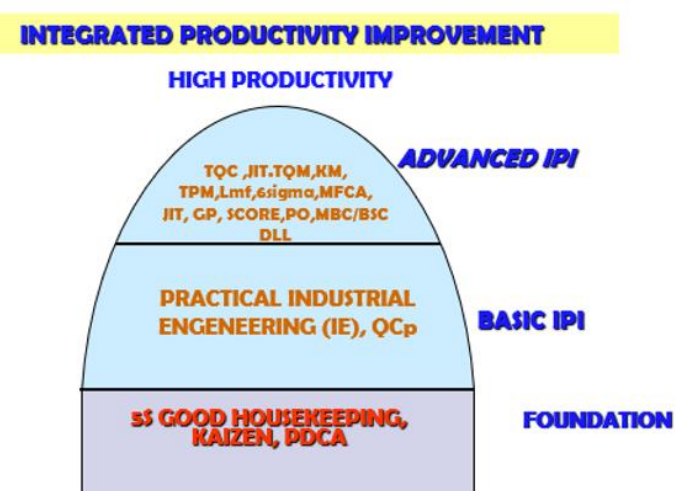

\section{Pelatihan 55 Good Housekeeping}

\begin{tabular}{|c|c|c|}
\hline $\begin{array}{c}5 \mathrm{~S} \\
\text { (INDONESIA) }\end{array}$ & $\begin{array}{c}5 \mathrm{~S} \\
\text { (JEPANG) }\end{array}$ & PRINSIP \\
\hline Sisih & SEIRI & $\begin{array}{c}\text { Singkirkan barang yang tidak } \\
\text { diperlukan }\end{array}$ \\
\hline Susun & SEITON & $\begin{array}{l}\text { Menyusun, Membenahi } \\
\text { tempat penyimpanan barang }\end{array}$ \\
\hline Sasap & SEISO & $\begin{array}{l}\text { Melaksanakan prosedur } \\
\text { Kebersihan harian }\end{array}$ \\
\hline Sosoh & SEIKETSU & $\begin{array}{l}\text { Pertahankan/standar Sisih, } \\
\text { Susun dan Sasap }\end{array}$ \\
\hline Suluh & SHITSUKE & $\begin{array}{c}\text { Jadikanlah sebagai suatu } \\
\text { kebiasaan }\end{array}$ \\
\hline
\end{tabular}

Gambar 6. Alat, Teknik dan Metode Peningkatan Produktivitas Sumber : (Anon 2020b)

Pelatihan Peningkatan Produktivitas yang dilaksanakan oleh pemerintah walaupun pada umumnya masih di level basic dapat membantu untuk meningkatkan produktivitas tenaga kerja dan perusahaan apabila penerapannya dilakukan secara terus menerus sehingga menjadi budaya produktivitas perusahaan tersebut. Contohnya karyawan-karyawan sebelum mendapatkan pelatihan budaya $5 \mathrm{~S}$ kerjanya asal jadi tidak sungguh-sungguh, tetapi setelah mendapatkan pelatihan peningkaktan produktivitas serta menerapkan budaya 5S mereka kerjanya lebih rapi, serius, dan cepat. Perusahaan akan memberikan rewards kepada karyawan yang produktivitasnya mengalami peningkatan. Hal ini berdampak juga terhadap pelanggan yang akan merasa lebih puas mendapat pelayanan serta meminimalkan kompalain dari pelanggan.

Diperlukan berbaikan dan penyempurnaan terhadap pelaksanaan pelatihan peningkatan produktivitas. Karyawan dan pihak menajemen perusahaan mengaharapkan pelatihan peningkatan produktivitas dapat dilakukan secara berkala dan bertahap, sehingga apapun pelatihannya bisa dikuasai secara lebih luas, bukan hanya di satu bidang saja agar ilmu dan pengalaman karyawan itu semakin bertambah dan karyawan semakin pintar. Pelatihan juga tidak hanya ditujukan untuk karyawan perusahaan tetapi juga pada pihak manajemen perusahaan sehingga memiliki satu pemahaman yang sama terhadap upaya peningkatan produktivitas. Materi yang disampaikan disesuaikan dengan kebutuhan perkembangan jaman serta berbasis pada penggunaan teknologi. Metode pelatihan lebih mengutamakan praktek langsung dan aplikasinya di tempat kerja tidak hanya di dalam kelas. 


\section{b. Bimbingan Konsultasi}

Terdapat beberapa faktor yang mendukung keberhasilan program bimbingan konsultasi antara lain:

- Komitment manajemen dalam mengikuti program bimbingan konsultasi secara umum cukup tinggi sehingga karyawan termotivasi untuk berperan aktif dalam setiap tahapan bimbingan.

- Karyawan belum banyak memahami alat, teknik, dan metode peningkatan produktivitas yang dapat diterapkan di perusahaan sehingga menumbuhkan antusiasme/keingintahuan karyawan untuk mempelajari dan menerapkannya di tempat kerjanya.

- Beberapa alat, teknik, dan metode peningkatan produktivitas, terutama implementasi 5S, relatif sederhana dan mudah diterapkan perusahaan untuk mengatasi permasalahan mendasar yang umumnya dialami perusahaan, yaitu masalah manajemen tata graha

Adapun faktor faktor yang menjadi penghambat keberhasilan program bimbingan konsultasi antara lain:

- Kesibukan karyawan oleh rutinitas kegiatan produksi mengakibatkan aktivitas bimbingan konsultasi agak terhambat .

- Rentang waktu pelaksanaan bimbingan konsultasi yang relatif singkat mengakibatkan beberapa kegiatan peningkatan produktivitas belum terselesaikn secara tuntas seratus persen.

- Koordiansi dan sinergitas antar bagian kurang memadai sehingga beberapa kegiatan peningkatan produktivitas masih bersifat parsial dan sporadis, belum secara keseluruhan. sehingga hasil kegiatan bimbingan konsultasi belum dapat menggambarkan kinerja perusahaan secara keseluruhan.

Selain terjadi peningkatan pada beberapa indikator Perusahaan peserta Kegiatan Bimbingan Konsultasi juga merasakan manfaat lain, yaitu:

- Kepekaan karyawan untuk mengenali permasalahan yang muncul di tempat kerja dan memunculkan ide solusinya semakin meningkat.

- Tanggung jawab karyawan terhadap kualitas proses maupun hasil pekerjaannya semakin meningkat.

- Kerjasama antara karyawan dalam satu kelompok kerja maupun antar kelompok kerja semakin solid.

- Semangat kerja karyawan semakin meningkat

Secara umum ada beberapa kegiatan yang bersifat pengembangan /tindak lanjut yang akan dilakukan oleh perusahaan peserta Bimbingan Konsultasi, antara lain:

- Beberapa kegiatan peningkatan produktivitas akan terus ditindaklanjuti, mengingat rencana kerja belum terselesaikn secara tuntas seratus persen.

- Kegiatan peningkatan produktivitas akan dikembangkan dan dilakukan pada seluruh bagian perusahaan.

JCommdev Vol 2, No. 3, 2021, hlm. 94 - 105 


\section{c. Penghargaan Sidhakarya dan Paramakarya}

Penganugerahan Produktivitas di Indonesia dikenal dengan nama Siddhakarya dan Paramakarya. Penghargaan Produktivitas Siddhakarya dan Paramakarya diselenggarakan sejak tahun 1994 atas persetujuan Presiden R.I tanggal 8 Januari 1993. Pemberian penghargaan ini merupakan tindak lanjut dari program Pelatihan Peningkatan Produktivitas dan Bimbingan Konsultasi, di mana pemerintah memberikan apresiasi untuk perusahaan dan karyawannya yang berhasil mengimplementasikan budaya kerja produktiv. Penghargaan Produktivitas Siddhakarya dan Paramakarya diselenggaran dengan maksud meningkatkan kesadaran, pemahaman dan komitmen peningkatan produktivitas, khususnya di kalangan dunia usaha \& dunia industri (DUDI

Pemberian Penghargaan Produktivitas Siddhakarya dan Paramakarya bertujuan; Meningkatkan komitmen dan upaya-upaya peningkatan produktivitas DUDI dan Meningkatkan produktivitas dan daya saing DUDI. Pemberian Penghargaan Produktivitas Siddhakarya dan Paramakarya dilakukan melalui penilaian performa usaha. Salah satu persyaratan untuk dapat mengikuti seleksi untuk mendapatkan perhargaan adalah perusahaan yang telah menerapkan Alat, Metode dan Teknik Peningkatan Produktivitas secara konsisten dan berkelanjutan serta perusahaan yang telah mendapatkan bimbingan peningkatan produktivitas baik dari lembaga produktivitas pemerintah atau lembaga produktivitas non pemerintah. Prosedur pemberian penghargaan di bidang produktivitas dapat dilihat pada gambar 7 .

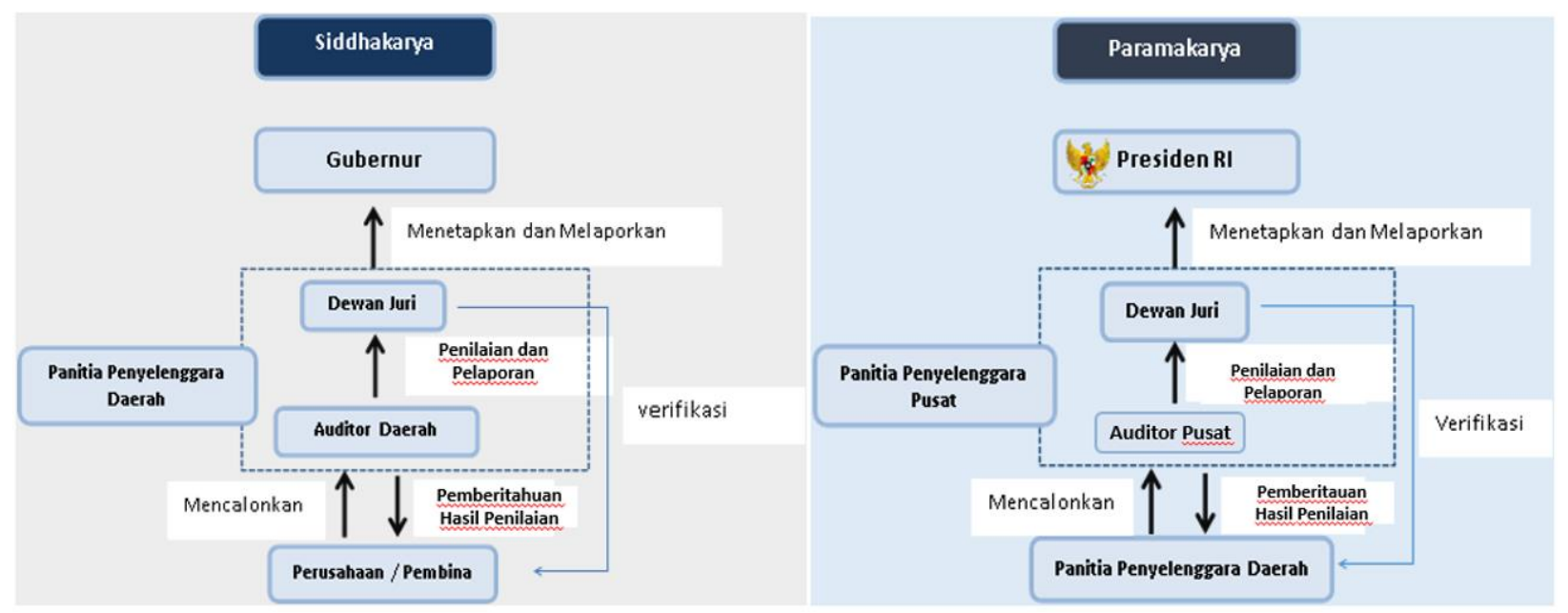

Gambar 7. Prosedur Pengusulan Pengusulan Penghargaan Sidhakarya dan Paramakarya Sumber : (Anon 2018)

\section{Simpulan dan Saran}

Penggunaan alat $5 \mathrm{~S}$ yang cukup sederhana dan mendasar terbukti effektif meningkatkan produktivitas perusahaan dan dampaknya dirasakan langsung oleh karyawan \& perusahaan peserta Pelatihan Peningkatan Produktivitas dan Bimbingan Konsultasi: pemborosan dapat dikurangi, sistem dan metode kerja lebih efisien dan efektif, kepedulian karyawan terhadap 
kebersihan meningkat, keteraturan tempat kerja, serta pemahaman pimpinan dan karyawan terhadap kualitas tempat kerja menjadi lebih baik.

Keberhasilan program Pelatihan Peningkatan Produktivitas dan Bimbingan kKnsultansi dapat dijadikan sebagai salah satu tolok ukur kepedulian semua pihak menyikapi budaya peduli peningkatan produktivitas bagi pengembangan usaha kecil dan menengah (UKM) di era krisis multidimensi bangsa Indonesia yang kini sedang terjadi.

Program-program peningkatan produktivitas tenaga kerja melalui Pelatihan Peningkatan Produktivitas dan Bimbingan konsultansi merupakan model pembinaan usaha kecil dan menengah yang cukup relevan dilakukan melalui pola pendampingan. Selain itu, program juga dapat menambah, wawasan dan kemampuan manajerial pimpinan maupun pekerja untuk meningkatkan produktivitasnya, yang pada akhirnya dapat memperkuat daya saing perusahaan kecil dan menengah di era kompetisi bisnis yang cukup ketat.

Perbaikan dan peningkatan program Pelatihan Peningkatan Produktivitas dan Bimbingan Konsultasi yang masih perlu dilakukan berkaitan dengan kontinuitas pelatihan, lingkup teknik, alat dan metode peningkatan produktivitas serta metode pelatihan yang diharapkan lebih menitik beratkan pada praktek dan aplikasi langsung di tempat kerja.

\section{Daftar Pustaka}

Anon. 2015. Produktivitas Panduan Untuk Pemula. Jakarta: Direktorat Bina Produktivitas, Ditjen Binalattas, Kementerian Ketenagakerjaan.

Anon. 2018. Pedoman Penganugerahan Produktivitas Siddhakarya Dan Paramakarya. Jakarta: Direktorat Bina Produktivitas, Ditjen Bina latas, Kementerian Ketenagakerjaan.

Anon. 2019. "Daya Saing Tenaga Kerja Indonesia Masih Tertinggal." Katadata.Co.Id. Retrieved December 3, 2020 (https://katadata.co.id/timpublikasikatadata/infografik/5e9a51914fa52/daya-saing-tenaga-kerja-indonesiamasih-tertinggal).

Anon. 2020a. Petunjuk Teknis Bimbingan Konsultansi Peningkatan Produktivitas. Jakarta: Direktorat Jenderal Pembinaan Pelatihan Dan Produktivitas Direktorat Bina Produktivitas Kementerian Ketenagakerjaan.

Anon. 2020b. Petunjuk Teknis Pelatihan Peningkatan Produktivitas. Jakarta: Direktorat Jenderal Pembinaan Pelatihan Dan Produktivitas Kementerian Ketenagakerjaan.

Dwi, Hadya Jayani. 2019. "Daya Saing Ekonomi Indonesia Turun." Katadata.Co.ld. Retrieved November 28, 2020 (https://katadata.co.id/ariayudhistira/infografik/5e9a4e5701b70/daya-saing-ekonomi-indonesia-turun).

Gugustomo, Gery. 2019. “Inovasi Dan Daya Saing SDM Indonesia Di Hardiknas 2019." Akurat.Co. Retrieved November 28, 2020 (https://akurat.co/news/id-610211-read-inovasi-dan-daya-saing-sdm-indonesia-dihardiknas-2019). 